\title{
Analysis of Students Critical Thinking using the Junior High School Student Online Module
}

\author{
Mulyono', Wahono Widodo ${ }^{2}$, Suyono ${ }^{3}$ \\ 1,2,3 Universitas Negeri Surabaya, Surabaya, Indonesia
}

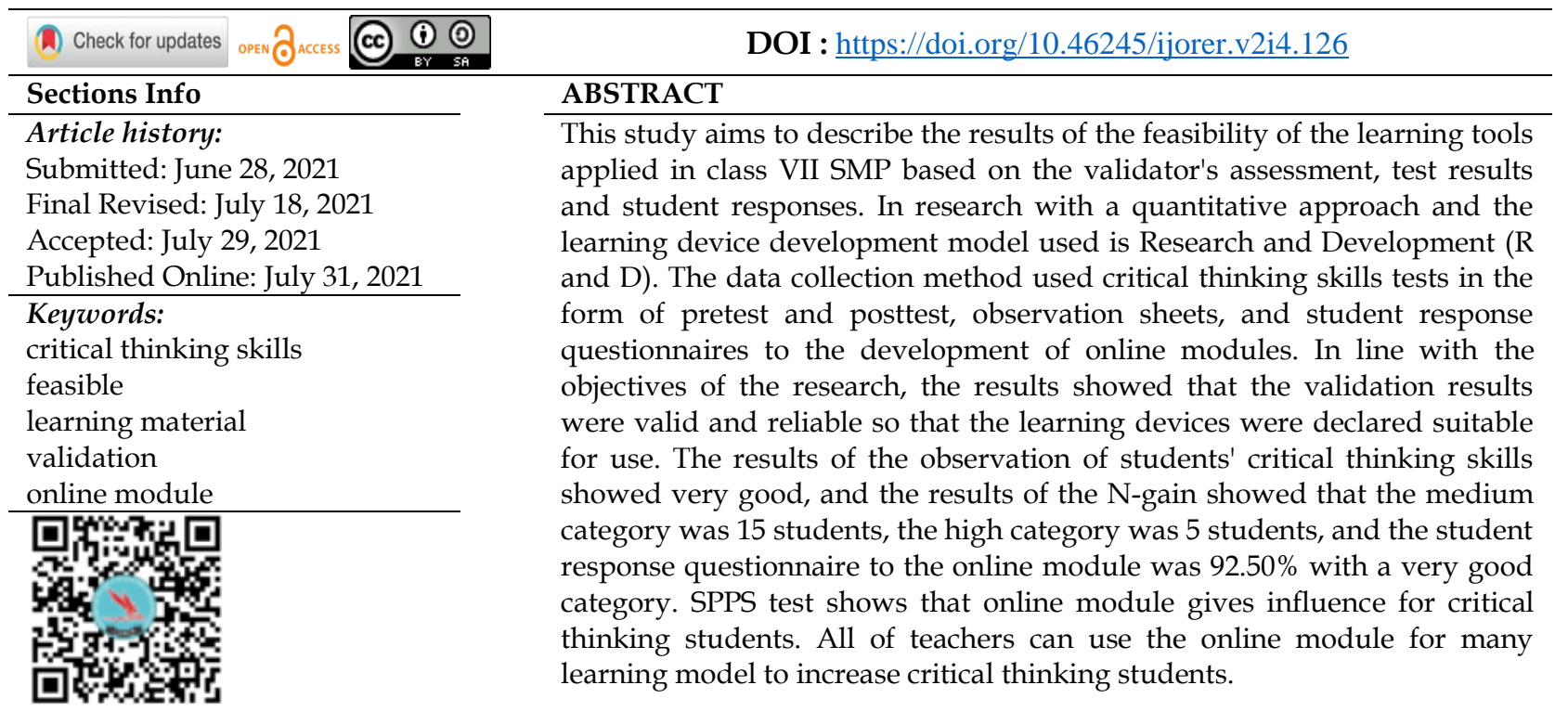

\section{INTRODUCTION}

Critical thinking has important role in study in order to students have open minded. The development of the world of education requires teachers to know how to manage learning to be more interesting and the skills needed by students can be facilitated in the 21st century and the openness of the flow of globalization which allows information and technology to develop very rapidly which will have an impact on changes in all aspects of life. Critical thinking is one side of being a critical person where the mind must be open, clear, and based on facts. Critical thinking aims to reflect one's ability to analyze, synthesize, and evaluate information (Roksa et al., 2017). Critical thinking means reflective thinking which focuses on deciding that believed act or something done (Fuad et al., 2017). The students' skill to think critically is still lacking, because of the teacher's limited skill to develop, as is well known in physics is known as a lesson full of formulas that are considered difficult (Alvionita et al., 2020).

Module is solution to empower students critical thinking because it completed by activity, training, and self-assessment (Nawawi, 2017). The module is learning materials which arranged systematically with easy to understand language by students (Handayani, 2018). Electronic Module Web-based can be interpreted as module teaching materials that are presented in electronic form and in- publish via a web using Content Management System (CMS) tools to presenting material and the Quiz Management 
System (QMS) as a practice tool with the system web-based automated assessment (Febrina et al., 2020). Module on line or electronic module is a digital medium whose display and systems The mathematical writing is intentionally made like a module that contains a series of learning activities interconnected by links and can be complemented by multimedia, and run with using a computer-based website (Arriany et al., 2020). Media that is integrated in educational technology when designed and used properly can improve the quality of learning outcomes.

One alternative that can be used to improve students' critical thinking skills in learning with heat material and its transfer is using online module learning tools. The purpose of this research is to produce an appropriate online module to cultivate students' critical thinking skills in learning with heat and its transfer material. Temperature and heat materials have a low level of mastery and high misconceptions (Nursyamsi et al., 2018). Mistakes occur when understanding several concepts, including (1) stating that specific heat is affected by mass, heat and temperature changes, (2) interpreting large specific heat as an object that easily experiences an increase in temperature, and (3) stating that heat capacity is affected by heat. and temperature rise (Taqwa et al., 2019). Module development is carried out for temperature and heat material because this material is a little difficult to learn because it is abstract which can cause various different thoughts for students (Hadiya et al., 2015).

\section{RESEARCH METHOD}

Learning instruments using online modules have been tested on a limited basis at Junior high school Al Ibrah Gresik class VII. The sample in this study was class VII as many as 20 students. The research design used was One Group Pretest Posttest Design, a descriptive quantitative approach. The data analysis used is to analyze critical thinking skills taken through pretest and posttest questions and the results are analyzed using the $\mathrm{N}$-gain score. Analysis was also carried out on the implementation of learning with online modules, student activities in learning using online modules, and the validity of the media using descriptive analysis. Another data analysis is analyzing student responses at the end of the lesson by giving questionnaires to students.

The instrument test made by the researcher consisted of 20 questions about heat and displacement in the form of multiple choice. Multiple choice questions will increase the variety of items that can be used in the assessment, so that the assessment instrument obtained can accommodate broad thinking skills (Hartini and Sukardjo, 2015). The validation results criteria are described in Table 1 and calculated by the following formula:

$$
\mathrm{R}=\frac{s}{N} \times 100 \%
$$

Informations:

(Widoyoko, 2017)

$\mathrm{R}=$ Average score

$S=$ Number of scores obtained

$\mathrm{N}=$ Maximum number of scores 
After knowing the validity value of each expert, then combining the results of expert validity and analyzing all expert validators using the following formula:

$$
\mathrm{M}_{\mathrm{R}}=\frac{\sum R}{N}
$$

(Sudijono, 2017)

Informations:

$\mathrm{M}_{\mathrm{R}} \quad=$ Average combined score

$\sum R \quad=$ Number of scores obtained

$\mathrm{N} \quad=$ The number of validators

The instrument has validly categorized if the instrument measures the mastery abilities in measured domain (Arifin, 2017). Instrument in this research has valid category after reaching more than $50 \%$ and the instrument is suitable for use (Riduwan, 2014).

Table 1. Criteria of validity coefficient.

\begin{tabular}{cc}
\hline Validity coefficient & Criteria \\
\hline $75 \leq \mathrm{VC} \leq 100$ & Very valid \\
$50 \leq \mathrm{VC}<75$ & Valid \\
$25 \leq \mathrm{VC}<50$ & Enough Valid \\
$0 \leq \mathrm{VC}<25$ & Less Valid \\
\hline
\end{tabular}

(Riduwan, 2014)

The reliability of the problem solving test instrument uses a Likert scale. The formula for calculating expert reliability use Percentage of Agreement $(\mathrm{R})$ analysis with reliable criteria if $\mathrm{R} 75 \%$ in the formula:

$$
\mathrm{R}=1-\left[\frac{A-B}{A+B}\right] \times 100 \%
$$

Informations:

(Mustaming et al., 2015)

$\mathrm{R} \quad=$ Reliability

A = Behavioral frequency with high observation

$\mathrm{B}=$ The frequency of behavioral aspects observed by observers by giving low observations

Data on the implementation of lesson plans in learning using online modules is descriptive qualitative, that is, counting the number of learning stages carried out divided by the total number of learning stages. In this assessment, the scale is 1 to 4 . The scores of the two observers are then averaged and interpreted in Table 2.

Table 2. Description of lesson plan validation scores.

\begin{tabular}{cc}
\hline Scala & Description \\
\hline $1,00-1,99$ & Not good \\
$2,00-2,99$ & Pretty good \\
$3,00-3,49$ & Good \\
$3,50-4,00$ & Very good \\
\hline
\end{tabular}


The test is used to determine students' critical thinking skills on heat and displacement materials. Students are said to be completed if the value is greater than the minimum completeness criteria, which is 70. Student learning mastery for critical thinking skills tests can be calculated using the following equation:

$$
\text { Mastery learning }=\frac{\text { total score obtained }}{\text { maximum score }} x 100 \%
$$

The results of completeness can be used as supporting data to determine whether students are stimulated by critical thinking skills or not. From the results obtained, then analyzed using the $\mathrm{N}$-gain score (normalized increase score) to determine the magnitude of the increase in students.

Table 3. N-Gain score criteria.

\begin{tabular}{cc}
\hline$<\mathrm{g}>$ & Information \\
\hline $\mathrm{g} \geq 0,7$ & High \\
$0,3<\mathrm{g}<0,7$ & Medium \\
$\mathrm{g} \leq 0,3$ & Low \\
\hline
\end{tabular}

(Hake, 1999)

This learning outcome of students did statistic inferential test (normality, homogeneity, and Wilcoxon). Students are said to have grown critical thinking skills if students experience an increase in learning outcomes from the tests given even though they have not reached the minimum completeness criteria specified at school.

\section{RESULTS AND DISCUSSION}

The research was conducted to determine the validity of the online module. The validation results on the content aspect are $90 \%$ with a very valid category with $95 \%$ reliability, the construct aspect is $86 \%$ with a very valid category with $92 \%$ reliability, and the language aspect is $94 \%$ with a very valid category with $96 \%$ reliability detail in Table 4.

Table 4. Online module validation results.

\begin{tabular}{lcc}
\hline \multicolumn{1}{c}{ Aspects } & Validity & Reliability \\
\hline Content & $90 \%$ & $95 \%$ \\
Construct & $86 \%$ & $92 \%$ \\
Language & $94 \%$ & $96 \%$ \\
\hline
\end{tabular}

The content aspect of the online module contains the validator's assessment of the material, introduction, learning scenarios, let's think, videos, worksheets, competency test questions. The online module on heat and its transfer is developed and structured contextually. This is in line with the constructivism view which states that knowledge cannot be transferred from teacher to student because the student's brain is not empty but already contains knowledge from previous experiences (Mujtahidin, 2014). 
Contextual material that is in accordance with student experience will make it easier for students to construct their knowledge with newly received knowledge (Trianto, 2014). The online module developed by the author is expected to be able to motivate students in learning so that student learning outcomes will increase after using the online module on heat and movement material and can train students to learn independently.

The second aspect assessed by the validator is the construct. This aspect assesses the layout, images, videos, forms of writing, and colors. Textbooks generally do not discuss how to learn meaningful science. Many science textbooks today place an overemphasis on the product of scientific facts and mathematical formulations (logical plane). The relationship of scientific concepts to experience, society, and technology is rarely done by book authors. As a result, when students are given problems related to everyday experiences or natural phenomena, many of them cannot explain or solve them according to scientific conceptions (Djudin, 2017). By adding certain types of images to the subject matter will be able to help students understand the lesson. Based on the description, the selection of animations and images is designed to have an optimal role in increasing students' understanding. Pictures and animations have an important role to convey learning messages that usually seem abstract in textbooks.

The third aspect assessed by the validator is the language aspect. The language aspect assesses the use of language in the online module of heat and its transfer. Verbal language, both spoken and written, must have a semantic code, grammar, and sentences with the right meaning. The language in the online module of heat and its transfer is a language that is easily understood by students and has a simple sentence structure. Language is also arranged communicatively so that students seem to be invited to interact with the online module.

Electronic Module Web-based can be interpreted as module teaching materials that are presented in electronic form and in- publish via a web using Content Management System (CMS) tools to presenting material and the Quiz Management System (QMS) as a practice tool with the system web-based automated assessment (Febrina et al., 2020). Module on line or electronic module is a digital medium whose display and systems The mathematical writing is intentionally made like a module that contains a series of learning activities interconnected by links and can be complemented by multimedia, and run with using a computer-based website (Arriany et al., 2020).

Table 5. Results of validation of learning implementation plans.

\begin{tabular}{ccc}
\hline Aspect of estimation & Validity & Reliability \\
\hline Format & $88 \%$ & $93 \%$ \\
Content & $83 \%$ & $95 \%$ \\
Language & $92 \%$ & $91 \%$ \\
\hline
\end{tabular}

The validator assesses the lesson plans from 3 aspects, namely the format, content, and language in the lesson plans. The results of the validation on the format aspect are $88 \%$ with a very valid category with $93 \%$ reliability, the content aspect is $83 \%$ with a very valid category with $95 \%$ reliability, and the language aspect is $92 \%$ with a very valid 
category with $91 \%$ reliability. The expert's assessment shows that the models, methods, and learning media are chosen appropriately so that it allows students to be active in online learning. The phases of the learning model are clearly written. Based on this, it can be stated that the prepared lesson plan is feasible to use.

The lesson plan developed by the author begins with motivation. This motivation aims to increase students' intrinsic motivation. Mujtahidin (2014) explained that lessons in class should increase students' intrinsic motivation. In this case, the teacher must improve the way of teaching so as to foster interest in learning and maintain student curiosity. The use of online modules is also an important part of the lesson plans prepared by the author. In online learning so that in conducting experiments, they experience difficulties both in terms of time, assistance, and tools and materials. However, students can gain virtual experience using online modules. The lesson plan developed by the author uses a problem-based learning model or Problem Based Instruction (PBI). This model aims to help students learn various skills and think critically according to experiences in everyday life (Mujtahidin, 2014). The PBI model is suitable for teaching heat material and its transfer using an online module compiled by the researcher. The teacher only provides a little guidance because all knowledge and activities for tests and learning activities have been included in the online module that can be applied on a mobile basis so that it can be used anywhere and anytime according to student needs.

Table 6. Validation results of student activity sheets.

\begin{tabular}{lcc}
\multicolumn{1}{c}{ Aspect } & Validity & Reliability \\
\hline Didactic Terms & $87 \%$ & $92 \%$ \\
Construction Terms & $93 \%$ & $95 \%$ \\
Technical Terms & $87 \%$ & $94 \%$ \\
\hline
\end{tabular}

The student worksheet developed by the author is then reviewed by the validator with the aim of producing a proper student worksheet. The validator assesses the online module of heat material and its transfer from 3 criteria, namely tactical requirements, construction requirements, and technical requirements. The results of the validation on the didactic requirements aspect is $87 \%$ with a very valid category with $92 \%$ reliability, the construction requirements aspect is $93 \%$ with a very valid category with $95 \%$ reliability, the technical requirement aspect is $87 \%$ with a very valid category with $94 \%$ reliability. Thus, student worksheet is very feasible to use. This is in accordance with one of the student work-sheet functions according to Djudin (2017), namely the material is easy for students to understand by using teaching materials.

Overall, the worksheets on heat materials and their transfers are in accordance with the requirements for the preparation of a good worksheet based on didactic, construction and technical requirements. Science textbook writers pay attention to stylistics, place emphasis on verbal argumentation, and reduce the number of new terms introduced. Definitions should be presented briefly and easily understood by students. Instead, explanations of concepts and principles are presented in a long and complete manner. Science textbooks should also contain existing and emerging technologies along with suggestions for how these technologies can be used in society. textbooks need to 
implement constructivism and conceptual change models that consider students' initial conceptions (Djudin, 2017).

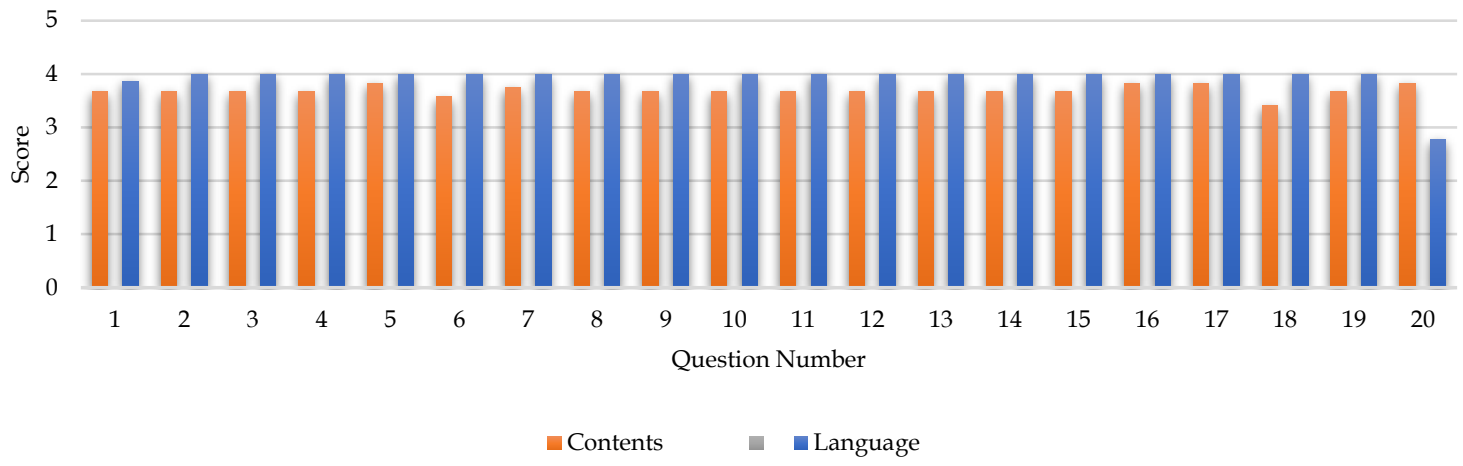

Figure 1. Question validation results diagram.

The critical thinking skills test developed by the author is a written test that aims to measure students' cognitive. This test consists of 20 multiple choice questions and can be done directly in the online module. Aspects that are assessed on the test questions are aspects of content, construction, and language. These aspects are reviewed and assessed as validators. The results of the validation of the test items are presented in Table 7. The results of the validator's assessment determine whether the items developed by the author can be used without revision, used with revisions or cannot be used. The results of the validation of the learning outcomes test compiled by the author concluded that the questions could be used with a few revisions. Of the 20 questions in accordance with the cognitive level aimed at measuring students' ability to understand the concept of heat material and its displacement.

Table 8. Observation results of critical thinking ability.

\begin{tabular}{llccc}
\hline \multicolumn{1}{c}{ Student activity } & Meet.1 & Meet.2 & Meet.3 & Average \\
\hline 1. Students try to know the information & $87,50 \%$ & $92,25 \%$ & $87,50 \%$ & $89,00 \%$ \\
$\begin{array}{l}\text { well } \\
\text { Students behave systematically and }\end{array}$ & $87,50 \%$ & $87,50 \%$ & $81,25 \%$ & $85,50 \%$ \\
$\begin{array}{l}\text { regularly with parts of the whole } \\
\text { problem. }\end{array}$ & $87,50 \%$ & $75,00 \%$ & $81,25 \%$ & $81,25 \%$ \\
$\begin{array}{l}\text { 3. Students seek explanations as much as } \\
\text { possible if possible }\end{array}$ & $93,75 \%$ & $90,75 \%$ & $93,75 \%$ & $92,75 \%$ \\
\hline $\begin{array}{l}\text { Students' ability to find a clear statement } \\
\text { of each question }\end{array}$ & & & & \\
\hline
\end{tabular}

Table 8 shows the observational data on critical thinking skills in learning. The average in three meetings of student activities trying to find out information well is $89.00 \%$, student activities behave systematically and regularly with parts of the whole problem at $85.50 \%$, student activities seek explanations as much as possible if possible by $81.25 \%$, and activity the ability of students to find a clear statement of each question is 
$92.75 \%$. The use of online modules has an important role in the learning activities carried out by the authors. Learning using the online module of heat and its transfer directs students to study hard. With online modules, students can view videos and read material repeatedly according to student needs. Electronic teaching materials also support open learning and can be owned by students because they are easy to share (share) for example through social media such as Facebook, WhatsApp, Telegram and the like (Yulaika et al., 2020). Teachers are expected to be able to design and compile teaching materials that play a role in determining the success of the learning and learning process (Kusumam et al., 2016). The results of observations of students ' critical thinking skills show that they are very good at learning with the help of online modules.

The explanation of the material is done using an online module so that students get information visually and auditory. Humans have separate channels in processing information for visual and auditory material. When the media presents information in the form of illustrations, animations, videos, and texts, the information will be processed by students into the visual channel while the ear goes to the auditory channel. Increased learning outcomes due to the interaction of students with the material shows the learning process is running as it should (Arozaq et al., 2017). While the written test is a test given to students at the same time and place for certain questions. Student learning outcomes are categorized as complete if students reach the minimum completeness criteria that have been determined by the school for science subjects, which is 70 . The results of the analysis of pretest, posttest, and N-gain score can be seen in Table 9.

Table 9. Completeness of student learning outcomes.

\begin{tabular}{|c|c|c|c|c|c|c|}
\hline \multirow{2}{*}{ Student } & \multicolumn{2}{|c|}{ Pre-Test } & \multicolumn{2}{|c|}{ Post-Test } & \multirow{2}{*}{ Gain Score } & \multirow{2}{*}{ Category } \\
\hline & Score & Criteria & Score & Criteria & & \\
\hline A1 & 65 & $\mathrm{TT}$ & 85 & $\mathrm{~T}$ & 0,57 & Medium \\
\hline A2 & 60 & $\mathrm{TT}$ & 90 & $\mathrm{~T}$ & 0,75 & High \\
\hline A3 & 55 & $\mathrm{TT}$ & 90 & $\mathrm{~T}$ & 0,77 & High \\
\hline $\mathrm{A} 4$ & 55 & $\mathrm{TT}$ & 85 & $\mathrm{~T}$ & 0,56 & Medium \\
\hline A5 & 55 & $\mathrm{TT}$ & 70 & $\mathrm{~T}$ & 0,33 & Medium \\
\hline A6 & 50 & $\mathrm{TT}$ & 80 & $\mathrm{~T}$ & 0,60 & Medium \\
\hline A7 & 50 & $\mathrm{TT}$ & 70 & $\mathrm{~T}$ & 0,40 & Medium \\
\hline A8 & 50 & $\mathrm{TT}$ & 70 & $\mathrm{~T}$ & 0,40 & Medium \\
\hline A9 & 45 & $\mathrm{TT}$ & 90 & $\mathrm{~T}$ & 0,82 & High \\
\hline A10 & 45 & $\mathrm{TT}$ & 90 & $\mathrm{~T}$ & 0,82 & High \\
\hline A11 & 45 & $\mathrm{TT}$ & 80 & $\mathrm{~T}$ & 0,64 & Medium \\
\hline A12 & 45 & $\mathrm{TT}$ & 80 & $\mathrm{~T}$ & 0,64 & Medium \\
\hline A13 & 45 & TT & 80 & $\mathrm{~T}$ & 0,64 & Medium \\
\hline A14 & 45 & $\mathrm{TT}$ & 75 & $\mathrm{~T}$ & 0,55 & Medium \\
\hline A15 & 45 & $\mathrm{TT}$ & 70 & $\mathrm{~T}$ & 0,46 & Medium \\
\hline A16 & 45 & $\mathrm{TT}$ & 70 & $\mathrm{~T}$ & 0,46 & Medium \\
\hline A17 & 40 & $\mathrm{TT}$ & 80 & $\mathrm{~T}$ & 0,67 & Medium \\
\hline
\end{tabular}




\begin{tabular}{lcccccc}
\hline \multirow{2}{*}{ Student } & \multicolumn{2}{c}{ Pre-Test } & \multicolumn{2}{c}{ Post-Test } & \multirow{2}{*}{ Gain Score } & \multirow{2}{*}{ Category } \\
\cline { 2 - 5 } & Score & Criteria & Score & Criteria & & 0,77 \\
\hline A18 & 35 & TT & 85 & T & & High \\
A19 & 25 & TT & 65 & TT & 0,53 & Medium \\
A20 & 10 & TT & 65 & TT & 0,61 & Medium \\
\hline Average & 45,50 & TT & 78,50 & T & 0,61 & Medium \\
\hline
\end{tabular}

Information:

$\mathrm{T} \quad=$ finished

TT $=$ not finished

Table 9 shows that from the pretest data, there are no students who can achieve the individual mastery determined by the school, which is 70. The low mastery score is because students are not clear about the heat and transfer material taught by the previous teacher. Science teachers learn textbook-oriented and acquire initial teaching practices from textbooks. The teacher teaches based on textbooks and emphasizes the process of memorizing scientific facts in a rhetoric of continuous information delivery (Djudin, 2017).

In learning, all plans are determined by the teacher and then conveyed to the students. In all these situations, students are not much involved and involved. Such teaching can hinder students' thinking processes. Students do not have the opportunity to manifest their potential and abilities. The number of students who reached the minimum completeness criteria after receiving learning using the online module on heat and transfer material based on the posttest results were 18 students $(90.00 \%)$, 2 students did not complete $(10.00 \%)$ because they are not optimal in absorbing the concepts in the online module and are not used to online learning. The students' average test scores increased from 45.50 to 78.50. N-gain score analysis showed an increase of 0.61 students and included in the medium category. Students who experienced an increase in the medium category were 15 students $(75.00 \%)$, while students who experienced an increase in the high category were 5 students $(25.00 \%)$. These results indicate that learning activities using online modules can foster critical thinking skills. Students learning outcome did SPSS test to know the normality, homogeneity, and Wilcoxon. The normality test in Table 10 has significance abnormal but the homogeneity test in Table 11 shows homogeneous. The test statistics in Table 12 use Wilcoxon signed ranks test shows that accepted significance and it shows module online can increase critical thinking.

Table 10. Tests of normality.

\begin{tabular}{ccccccc}
\hline & \multicolumn{3}{c}{ Kolmogorov-Smirnov(a) } & \multicolumn{3}{c}{ Shapiro-Wilk } \\
\cline { 2 - 7 } & Statistic & df & Sig. & Statistic & df & Sig. \\
\hline pretest & 0.283 & 20 & 0.000 & 0.866 & 20 & 0.010 \\
Post-test & 0.189 & 20 & 0.061 & 0.900 & 20 & 0.042 \\
\hline
\end{tabular}

$\mathrm{a}=$ Lilliefors Significance Correction

Table 11. Test of homogeneity of variance.

Levene
Statistic df1 df2 Sig.




\begin{tabular}{llcccc}
\hline \multirow{4}{*}{ data } & Based on Mean & 0.018 & 1 & 38 & 0.895 \\
& Based on Median & 0.045 & 1 & 38 & 0.833 \\
& Based on Median and with adjusted df & 0.045 & 1 & 29.142 & 0.833 \\
& Based on trimmed mean & 0.050 & 1 & 38 & 0.824 \\
\hline
\end{tabular}

Table 12. Test statistics (b) (Wilcoxon).

\begin{tabular}{lr}
\hline & posttest - pretest \\
\hline$Z$ & $-3.929(\mathrm{a})$ \\
Asymp. Sig. (2-tailed) & 0.000 \\
\hline
\end{tabular}

Success in improving student learning outcomes related to critical thinking skills should not be viewed as a result of online module assistance alone. The success of learning is the result of collaboration between technologies (online modules), student activities, learning objectives, learning implementation plans, and the role of the teacher contribute to the success of a learning. The results of the expert validation, teacher questionnaire, and student questionnaire showed that the interactive multimedia courseware is feasible for use in learning and effective in strengthening students' characters (Septiani et al., 2020). Multimedia is not just delivering information to students but multimedia must also be able to move students' cognitive abilities to actively construct their knowledge in learning and learning activities. Learning tools developed according to student needs will help students improve student learning outcomes, including learning media. Student responses to the online module developed by the author get a very good response. Based on the results of student response questionnaires, learning activities using interactive media can help students understand heat material and its transfer. Computers can provide a display that allows users to freely choose, synthesize, and elaborate the knowledge they want to understand so that computers will be very helpful if used as learning media (Munadi, 2012).

\section{CONCLUSIONS}

The results of the validation of the learning devices obtained varied validator assessment results as well as reliability. The results of the validation and reliability as a whole are in the very valid and reliable category so that the learning device is declared suitable for use. The results of observations of students' critical thinking abilities trying to find out information well with student activities behave systematically and regularly with parts of the whole problem, student activities seek explanations as much as possible if possible, and activity The ability of students to find a clear statement of each question is and the $\mathrm{N}$-gain results show that the medium category is 15 students, the high category is 5 students. Limitation off this study was so difficult to invite students on online learning. All of the teachers can use this module online to increase critical thinking skills.

\section{REFERENCES}

Alvionita, D., Prabowo, \& Supardi, Z. A. I. (2020). Problem based learning with the sets method to improve the student's critical thinking skill of senior high school. IJORER: 
International Journal of Recent Educational Research, 1(3), 246-260. doi.org/10.46245/ijorer.v1i3.46

Arifin, Z. (2017). Kriteria instrumen dalam suatu penelitian. Jurnal THEOREMS (The Original Research of Mathematics), 2(1), 28-36. doi.org/10.31949/th.v2i1.571

Arozaq, M., Aman, \& Sunarhadi, M. A. (2017). Implementation of reading guide strategy in global climate change material for enhancement of student learning outcome. Scientific Journal of Universitas Negeri Semarang, 2(2), 82-89. doi.org/10.15294/ijal.v2i2.10803

Arriany, I., Ibrahim, N., \& Sukardjo, M. (2020). Pengembangan modul online untuk meningkatkan hasil belajar Ilmu Pengetahuan Sosial (IPS). Jurnal Inovasi Teknologi Pendidikan, 7(1), 52-66. doi.org/10.21831/jitp.v7i1.23605

Depdiknas. (2018). Panduan penyusunan kurikulum 2013 jenjang pendidikan dasar dan menengah. Jakarta: Depdiknas.

Djudin, T. (2017). Kriteria dan bentuk buku teks sains masa depan. Jurnal Pendidikan Informatika dan Sains, 6(2), 144-154. doi.org/10.31571/saintek.v6i2.640

Febrina, T., Leonard, \& Astriani, M. M. (2020). Pengembangan modul elektronik matematika berbasis web. JKPM: Jurnal Kajian Pendidikan Matematika, 6(1), 27-36. doi.org/10.30998/jkpm.v6i1.8141

Fuad, N. M., Zubaidah, S., Mahanal, S., \& Suarsini, E. (2017). Improving junior high schools' critical thinking skills based on test three different models of learning. International Journal of Instruction, 10(1), 101-116.

Hadiya, I., Halim, A., \& Adlim. (2015). Pengembangan modul pembelajaran suhu dan kalor berbasis masalah untuk SMA dalam upaya meningkatkan minat belajar siswa. Jurnal Pendidikan Sains Indonesia, 3(1), 81-92.

Hake, R. R. (1999). Design-based research in physics education: A review. Routledge.

Handayani, M. (2018). Developing thematic-integrative learning module with problembased learning model for elementary school students. Jurnal Prima Edukasia, 6(2), 166176. doi.org/10.21831/jpe.v6i2.14288

Hartini \& Sukarjo. (2015). Pengembangan higher order thinking multiple choice test untuk mengukur keterampilan berpikir kritis IPA kelas VII SMP/MTs. Jurnal Inovasi Pendidikan IPA, 1(1), 86-101. doi.org/10.21831/jipi.v1i1.4535

Kemendikbud. (2013). Permendikbud Nomor 65 Tahun 2013 tentang Standar Proses. Jakarta: Kementerian Pendidikan dan Budaya

Kusumam, A., Mukhidin, \& Hasan, B. (2016). Pengembangan bahan ajar mata pelajaran dasar dan pengukuran listrik untuk sekolah menengah kejuruan. Jurnal Pendidikan Teknologi dan Kejuruan, 23(1), 28 -39. doi.org/10.21831/jptk.v23i1.9352

Mujtahidin. (2014). Teori belajar dan pembelajaran. Surabaya: Pena Salsabila.

Munadi, Y. (2012). Media pembelajaran: Sebuah pendekatan baru. cetakan keempat. Jakarta: Gaung Persada.

Mustaming, A., Mochammad, C., \& Luthfiyah, N. (2015). Pengembangan perangkat pembelajaran memperbaiki unit kopling dan komponen-komponen sistem pengoperasiannya dengan model discovery learning untuk meningkatkan hasil 
belajar siswa kelas XI otomotif SMK Negeri 2 Tarakan. Jurnal Pendidikan Vokasi: Teori dan Praktek, 3(1), 81-95.

Nawawi, S. (2017). Developing of module challenge based learning in environmental material to empower the critical thinking ability. Jurnal Inovasi Pendidikan IPA, 3(2), 212-223. doi.org/10.21831/jipi.v3i2.15988

Nursyamsi, Sujiono, E. H., \& Yani, A. (2018). Identifikasi miskonsepsi materi fisika suhu dan kalor menggunakan CRI pada peserta didik kelas XI MIA SMA negeri 8 Bulukumba Tahun Ajaran 2015/2016. Jurnal Sains dan Pendidikan Fisika, 14(2), 44-54.

Riduwan. (2014). Dasar-dasar statistika. Bandung: Alfabeta.

Roksa, J., Trolian, T. L., Pascarella, E., \& Kilgo, C. A. (2017). Racial inequality in critical thinking skills: the role of academic and diversity experiences. Research in Higher Education, 58(2), 119-140. doi.org/10.1007/s11162-016-9423-1

Septiani, A. N. S. I., Rejekiningsih, T., Triyanto, \& Rusnaini (2020). Development of interactive multimedia learning courseware to strengthen students character. European Journal of Educational Research, 9(3), 1267-1279. doi.org/10.12973/eujer.9.3.1267

Sudijono, A. (2017). Pengantar statistik pendidikan. Jakarta: PT Raja Grafindo Persada. Sugiyono. (2013). Metode penelitian pendidikan. Bandung: Alfabeta

Taqwa, M. R. A., Priyadi, R., \& Rivaldo, L. (2019). Pemahaman konsep suhu dan kalor mahasiswa calon guru. JPF: Jurnal Pendidikan Fisika, 7(1), 56-67. doi.org/10.24127/jpf.v7i1.1547

Trianto. (2014). Mendesain model pembelajaran model pembelajaran inovatif, progresif, dan kontestual. Jakarta: Prenadamedia Group

Widoyoko, E. (2017). Teknik Penyusunan Instrumen Penelitian. Yogyakarta: Pustaka Pelajar.

Yulaika, N. F., Harti, \& Sakti, N. C. (2020). Pengembangan bahan ajar elektronik berbasis flip book untuk meningkatkan hasil belajar peserta didik. JPEKA: Jurnal Pendidikan Ekonomi, Manajemen, dan Keuangan, 4(1), 67-76. doi.org/10.26740/jpeka.v4n1.p67-76

\footnotetext{
*Mulyono (Corresponding Author)

Postgraduate Program, Science Education

Universitas Negeri Surabaya

Jl. Lidah Wetan, Surabaya, Jawa Timur, Indonesia

Email: mulyono.19041@mhs.unesa.ac.id
}

\section{Dr. Wahono Widodo, M.Si}

Postgraduate Program, Science Education

Universitas Negeri Surabaya

Jl. Lidah Wetan, Surabaya, Jawa Timur, Indonesia

Email: wahonowidodo@unesa.ac.id

\section{Prof. Dr. Suyono, M.Pd}

Postgraduate Program, Science Education

Universitas Negeri Surabaya

Jl. Lidah Wetan, Surabaya, Jawa Timur, Indonesia

Email: suyono@unesa.ac.id 